\title{
EL COMPLEJO ECLECTICISMO DE LAS TRADUCCIONES EN LA REVISTA CÁNTICO COMO FISURAS IDEOLÓGICAS EN LA ÉPOCA DE FRANCO
}

\author{
THE COMPLEX ECLECTICISM OF THE TRANSLATIONS \\ IN THE JOURNAL CÁNTICO AS SIGNS OF IDEOLOGICAL \\ OVERSIGHTS DURING THE FRANCO ERA
}

\section{Juan de Dios TORRALBO CABALLERO}

Universidad de Córdoba

torralbocaballero@uco.es

\begin{abstract}
Resumen: Este artículo estudia las traducciones de poesía en la revista Cántico a la luz de la era franquista. Se aborda la inclusión de poetas comunistas o socialistas como W. H. Auden, André Gide, Louis Aragon y Salvatore Quasimodo analizando también la presencia de escritores próximos al fascismo como Giuseppe Ungaretti. Destaca la existencia de poesía religiosa junto a la colaboración de escritores próximos al régimen de Franco como Joaquín de Entrambasaguas, lo cual se interpreta no solamente como predilección estética sino también como mecanismos para evitar la censura. La inclusión de poesía catalana y gallega es otro aspecto que permite corroborar la apertura que esta revista aporta al panorama literario español.
\end{abstract}

Palabras clave: Grupo Cántico. Revista Cántico. Traducción Literaria. Autocensura. Franquismo.

Abstract: This paper studies the translations of poetry in the journal
Cántico with reference to the Francoist age. It addresses the inclusion
of Communist and Socialist poets like W.H. Auden, Andre Gide, Louis
Aragon, and Salvatore Quasimodo also analysing, conversely, the presence
of writers sympathetic to fascism, such as Giuseppe Ungaretti. It points
out the presence of religious poetry, along with contributions by writers 
cosy with the Franco regime, like Joaquín Entrambasaguas, these being interpreted not only as aesthetic predilections, but also maneuvers to avoid censorship. The inclusion of poetry in Catalan and Galician is another aspect evidencing how the journal proved able to foster openness on the Spanish literary scene, despite the censorship to which it was exposed.

Key Words: Cántico Group. Cántico Review. Literary Translation. Selfcensorship. Franquism.

\section{INTRODUCCIÓN}

Fanny Rubio establece que las revistas de la postguerra "fueron 'puertos francos' [...] que acogieron en nombre de esta concepción las colaboraciones más dispares, la onomástica más cercana a una pluralidad que socialmente no tuvo espacio para manifestarse" (2003b: 55). En 1976, la profesora Rubio, en su conocida clasificación de las revistas españolas de postguerra, circunscribe la revista Cántico a una división ecléctica (2003a: 45), junto a Poesía Española, Proel o Corcel ${ }^{1}$. La mencionada investigadora también señala las que "intentaron desde posiciones oficiales la recuperación de ciertos valores proscritos (por ejemplo, Escorial o Lazarillo)", junto a otras "procedentes de medios universitarios" que "tendieron un puente hacia el realismo (por ejemplo, Raiz, Acento Cultural o Praxis)" o que se inclinaban hacia "el vanguardismo" (por ejemplo, Problemática 63). El último grupo que diferencia es el de "tipo religioso" (donde se encuadran Ángelus, Uriel o Veritas).

Manuel J. Ramos Ortega, por su parte, incide en la dicotomía entre Espadaña y Garcilaso al categorizarlas como "corriente rehumanizadora" y "corriente clasicista", sumando el tercer grupo de "continuadores de la tradición de las revistas y grupo el 27" (Ínsula, es un ejemplo) donde sitúa

\footnotetext{
${ }^{1}$ Fanny Rubio especifica que estas revistas son "portadoras de una directriz definida y confesional en diversos sentidos" (Rubio, 2003a: 45). En este segundo conjunto distingue las postsurrealistas (como Postismo, La Cerbatana, Doña Endrina o Trilce), las que contenían una elevada carga ideológica (como Cuadernos de Literatura Contemporánea, El Español, La Estafeta Literaria o Si). Dentro de este apartado señala las revistas que "respondían a la impaciencia y a los apasionados impulsos de sus artífices - algunos las llamaron tremendistas-(Espadaña, Ansí o La Isla de los Ratones...)".
} 
a Cántico, "pero conservando muy claramente su independencia como grupo aparte de cualquier consigna o escuela" (2001: 35). Ciertamente el contenido de la revista cordobesa presenta una simbiosis de temas diversos que permite tal clasificación. Sin embargo, una mirada crítica a las traducciones albergadas en sus páginas permite deducir un nuevo conjunto de conclusiones.

Dolores Romero López (1995: 243-272) en su trabajo titulado "Un tributo al análisis de las revistas españolas de posguerra Trabajos y Días (Salamanca, 1946-1951)" concluye que España tenía una vida intelectual atenta a lo que estaba ocurriendo en otros países a pesar de la dictadura. Esta deducción de la profesora Romero a tenor de la revista salmantina se engasta en las premisas operacionales de nuestro trabajo, es decir, en el interés que los miembros del Grupo Cántico mostraban hacia las novedades internacionales tal como evidencia el contenido de su revista (1947-1949, 1954-1957).

A pesar de las investigaciones existentes, Lucía Montejo Churruaga (2014: 66) lamenta la falta de estudios sobre revistas inmediatamente posteriores a la Guerra Civil española. Estimamos que esta carencia investigadora se acrecienta en el caso de las traducciones publicadas en las páginas de dichas revistas. A la luz de cuanto hemos podido consultar, se infiere que falta mucho por hacer en lo que atañe a las traducciones incluidas en las revistas de poesía durante la era de Franco. Pioneros resultan en este sentido los trabajos de Jacqueline Hurtley (1989), que abordan la traducción literaria en España durante la dictadura y los estudios de Sergio Lobejón $(2008,2009)$ que indagan la huella de la censura en las traducciones del inglés desde 1939 hasta 1978. Antonio Rivero Machina (2016: 540-548; 2017: 343-353) ha realizado una panorámica sobre la abundante presencia de poesía extranjera traducida en las revistas poéticas de los años cuarenta, mientras que Juan de Dios Torralbo Caballero ha indagado las referencias internacionales (2017) y las traducciones (2018a) en Cántico profundizando en las inglesas (2018b) e italianas (2019). Los fragmentos internacionales, empero, aún no han sido estudiados desde el ángulo aquí propuesto.

Con este trabajo confirmamos que la selección y la plasmación del corpus de literatura traducida en la revista Cántico responden a unas motivaciones concretas dignas de estudiar. Nuestra premisa de partida es que las revistas literarias fueron, en época de Franco, un vehículo 
expresivo para los intelectuales del momento ya que sus páginas atestiguan - de modo directo o tangencial - sus reacciones respecto a la dictadura (Blanco, 2000: 332). Por consiguiente, el objetivo de este trabajo es valorar a los autores traducidos con especial hincapié en la pléyade que podamos asociar al bando diletante con la dictadura, ahondando también en los temas de las traducciones para evidenciar si cumplían solamente un requisito formal y estético o si eran poemas de compromiso y de vanguardia. Asimismo, se pretende analizar los poemas y la ideología de los autores para inferir una serie de conclusiones sobre Cántico en tiempos de censura. Con todo ello, esta investigación quiere reflexionar sobre cómo las traducciones, al ser fragmentos, son capaces de romper con la ideología dominante y transgredir el sistema en pro de nombres que de otra manera hubieran resultado prohibidos. Finalmente se colige que, durante el régimen de Franco, al menos en este aspecto literario, se puede hablar de "heterogeneidad", término aplicado de manera específica por Fanny Rubio (2003a: 384) a la revista que nos ocupa y por Jeroen Oskam (1991: 121) de manera global a las publicaciones periódicas de postguerra.

En 1976, Fanny Rubio ya había inferido en relación con la revista cordobesa el "sentido de diversidad que Cántico iba consiguiendo, mostrado a base de la heterogeneidad de los autores que albergaba" (2003a: 384). Dos años después, Guillermo Carnero subrayaba el "eclecticismo" que él apreciaba más claramente en la segunda época de la revista (2009: 61). En 1997, en el Seminario de Poesía "Cincuenta años de Cántico", celebrado en Córdoba, Fanny Rubio postulaba que "Cántico cumplió uno de los papeles más difíciles que adjudicarse pueda a una revista de poesía de la inmediata posguerra: el de la equidistancia, teniendo en cuenta, incluso, su heterogeneidad y apertura" (2003b: 63). Los parámetros del eclecticismo, la equidistancia, la heterogeneidad y la apertura, estamos plenamente de acuerdo, son rasgos definidores de Cántico.

\section{LA REVISTA CÁNTICO EN SU CONTEXTO}

Las revistas de la España de postguerra más conocidas son Garcilaso y Espadaña. La primera se considera “como la voz del régimen², con unas

\footnotetext{
${ }^{2}$ Siguiendo el paradigma teorizado por Louis Althusser (1970), que concibe al Estado como un aparato represivo el cual permite a las clases dominantes asegurar su dominio sobre
} 
ideas un poco del imperio, un tanto trasnochadas" en tanto que la segunda era una "revista de tipo social, empezaba ya a haber una cierta resistencia, pero la verdad es que aquello era una resistencia vigilada por el régimen, que no hubiera permitido de ningún modo que aquellos poetas leoneses se salieran del tiesto". El compromiso del grupo Cántico es "el compromiso con la poesía [...] el volver a la poesía magnífica que nos habían dejado en puertas los poetas de la Generación del 27 y, más concretamente, los modernistas con Manuel Machado, Juan Ramón"'s. Guillermo Carnero predica, cargado de razones, que "Cántico revista rompe en 1947 la atonía literaria de Córdoba" (2009: 51).

También Pablo García Baena (1923-2018) es quien nos deja por escrito esta reflexión: "Es admirable que la llama de los jóvenes que fundaron Cántico supiera nadar por el agua fría de Garcilaso, de Espadaña, del existencialismo impostado y del mesianismo político que ya empezaba a despuntar" (2007: xvii-xviii). Ricardo Molina —continúa Pablo - "clamaba en las páginas finales de los sucesivos números de la revista contra la gesticulación existencial, la angustia retórica, la tragedia convencional y la imposición del poema al programa político, y pedía atención a la belleza, musicalidad y versatilidad [...]" (2007: xviii). Otra premisa de fondo es la siguiente afirmación del propio García Baena confirmando que los textos originales eran en España de difícil acceso en su gran mayoría puesto que "tenían que conseguirse forzosamente en los infiernos de algunas bibliotecas y librerías de la capital o se obtenían por préstamos clandestinos del Lycée Françáis de Madrid" (en Reyes, 2008: 144).

las clases dominadas, consideramos como punto de partida que los aparatos represivos del estado - mediante los tribunales, la administración y el gobierno-intervienen en los aparatos ideológicos del estado como son la cultura y la información. De esta forma, la esfera del poder genera de manera férreamente gestionada una ideología determinada que el pueblo, en su sumisión, la debe asumir. Una aplicación teórica del modelo althusseriano puede consultarse en el trabajo de Diego Santos Sánchez (2015: 170-184). Según Jordi Gracia y Domingo Ródenas de Moya (2015: 22), "la censura fue el instrumento más concreto de vigilancia ideológica”. Jeroen Oskam (1991: 120) disertó sobre el aspecto negativo o destructivo de la censura sin desdeñar la consecuencia positiva o productiva de la misma.

${ }^{3}$ Son declaraciones de Pablo García Baena en la entrevista realizada por Raquel Chang-Rodrigues y Antonio Garrido, del Instituto Cervantes y The City College of New York, producida por City University Television, en el programa "Charlando con Cervantes", en 2001. 
La autocensura, que no puede objetivarse en todos los casos, pensamos que está presente en la distribución, diseño y elección del contenido en la revista Cántico donde predomina la presencia de un número significativo de poesía traducida de otras lenguas. Con todo, conviene tener presente que la censura fue más intransigente con las artes que iban dirigidas a un público mayor (Neuschäfer, 1994: 87), como el cine y el teatro, aplicándose de manera más flexible a la novela y a la poesía (Muñoz, 2006: xxxiv).

La Ley de Prensa fue promulgada en abril de 1938 (BOE 23/04/1938) y, como es sabido, señaliza la censura ejercida por el bando ganador de la Guerra Civil. Berta Muñoz Cáliz segmenta la vigencia de la censura en varios periodos. El primero, que culmina hacia 1941, se caracteriza por su mayor exigencia (se ejecuta por un grupo falangista encabezado por Serrano Súñer). A continuación, se acendra el "discurso nacional-católico" (Muñoz, 2006: xxxvi) en el que se robustece "el modelo informativo totalitario" hasta el año 1962 que dependerá de Manuel Fraga. Dentro de este periodo destaca un paréntesis de seis años de leve intento de apertura (en este hiato la censura no depende del Ministerio de Información sino del Ministerio de Educación), desde 1945 hasta 1951. En esta etapa, más concretamente en octubre de 1947, es cuando nace la revista que se aborda en el presente estudio ${ }^{4}$.

El 28 de julio de 1951 Juan Aparicio López es nombrado Director General de Prensa, ostentando el cargo hasta 1957. Desde 1941 hasta 1945 había ocupado el puesto de Delegado Nacional de Prensa, fundando, entre otras, las revistas Fantasía, El Español y La Estafeta Literaria ${ }^{5}$ en 1944. Este político de Guadix reforzó el control de la censura (Rodríguez, 2008: 923) aumentando el número de personas implicadas en los procedimientos censorios; de hecho, Manuel L. Abellán denomina a estos años de la censura "época gloriosa" (1980: 110).

Los ocho primeros números de Cántico (1947-1949) se publican durante estos años de suave relajación en la censura; es entonces cuando la

\footnotetext{
${ }^{4}$ Los años 60 viven otro aperturismo con Manuel Fraga (1962-1969) que se esfuma con el liderazgo de Alfredo Sánchez Bella en el Ministerio de Información, perteneciente al gobierno de Carrero Blanco. Desde 1974 se aprecia otra época de liberalización con Pío Cabanillas como Ministro de Información. Berta Muñoz Cáliz (2006) explica estas etapas en su citado libro. En su tesis doctoral se encuentran abordadas de modo más detallado (Muñoz, 2005).

${ }^{5}$ En 1953 la dirige Luis Rosales.
} 
revista cordobesa difunde traducciones de poetas comunistas o socialistas ingleses y franceses tales como W. H. Auden (1907-1973) o André Gide (1869-1951) en diciembre de 1947; Louis Aragon (1897-1982) en febrero de 1948 y Charles Péguy (1873-1914) en abril de 1948. Sin embargo, el 16 de julio de 1949, Ricardo Molina (1916-1968) escribía a Luis Rosales estas palabras — de axial importancia para entender mejor la situaciónque se leen entre las páginas primera y segunda de la siguiente carta, la cual hemos encontrado en el Archivo Histórico Nacional: "Cántico atraviesa una crisis: dificultades 'censorias'. Espero vencerlas":

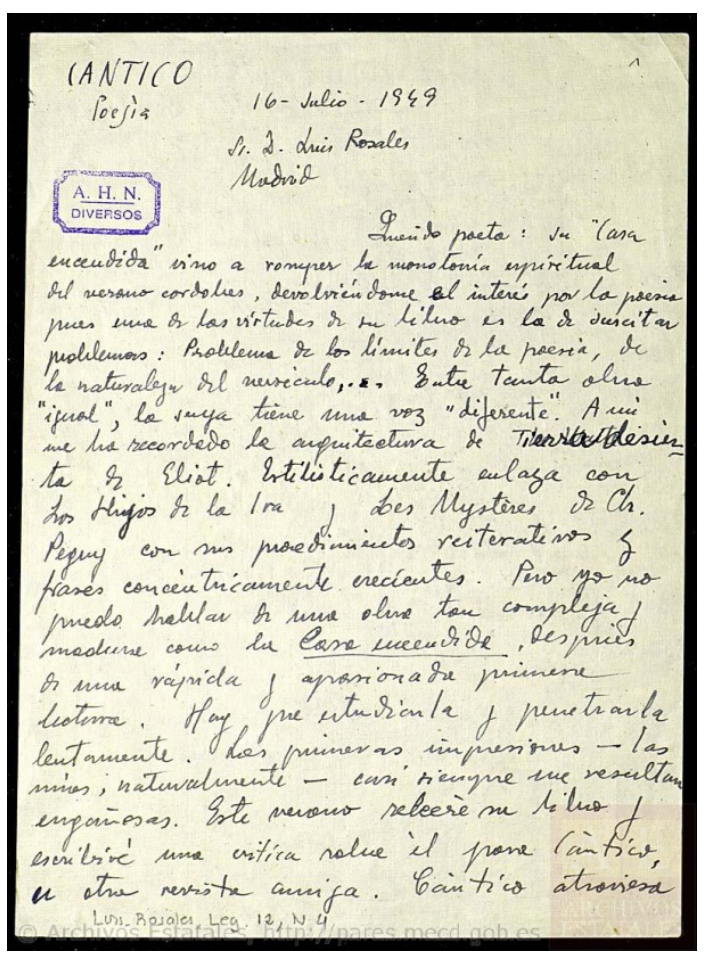

Figura 1. Carta de Ricardo Molina a Luis Rosales 


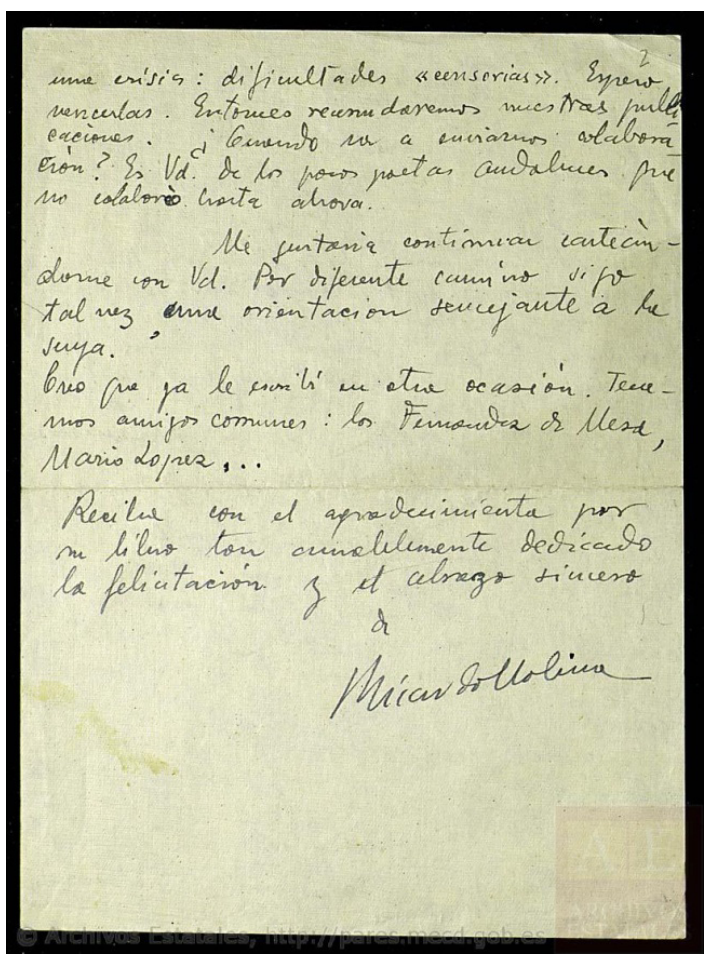

Figura 2. Carta de Ricardo Molina a Luis Rosales

El lamento de Ricardo Molina sobre la censura ${ }^{6}$ consideramos que ofrece una explicación sobre la interrupción que sufre la publicación desde enero de 1949 hasta su renacimiento en abril de 1954, cuando comienza la segunda época. La revista interrumpe su edición a comienzos de 1949 y precisamente seis meses después Ricardo Molina confiesa a Luis Rosales que estaban atravesando problemas "censorios".

Durante la segunda época de Cántico (1954-1957) también

\footnotetext{
${ }^{6}$ No hemos hallado referencias a la censura de Cántico en el Archivo General de la Administración. Al contrario que ocurre con la censura de libros, películas y representaciones teatrales, cuya expresión documental se organiza en largas series de expedientes que individualizan cada producto cultural, no hemos localizado una serie similar de censura para las publicaciones periódicas no diarias, en particular para Cántico, y en general, para la prensa, con anterioridad a 1966. En cambio, hemos hallado alusiones a Ínsula, algunas de las cuales reflejaremos en este trabajo porque están relacionadas con el mismo contenido que la revista cordobesa difunde.
} 
hallamos material digno de estudio como son los poemas sobre la guerra de Dylan Thomas (1914-1953) o Kathleen Raine (1908-2003), las poesías en gallego o en catalán, el homenaje a Cernuda $^{7}$ o la traducción de poetas italianos como Giuseppe Ungaretti (1888-1970). La censura criticó la presencia foránea en algunas revistas; por ejemplo, respecto al número cuadragésimo de Ínsula la "Inspección de Revistas" recogía la siguiente nota, fechada el 22 de abril de 1949: "Aire general, el mismo de siempre, esto es, de exaltación de valores más o menos ajenos al campo católico y de abundante información de firmas y movimientos literarios anglosajones y franceses"8. En el caso de Cántico es notable tanto la presencia de literatura gala como de poesía inglesa, por lo que se deriva que la dimensión extranjera señalada por la censura también está presente en la revista cordobesa.

Por consiguiente, todas estas novedades publicadas en la revista andaluza, que innovaron en el canon cultural y literario español, gozaron de la aceptación de los informadores locales y, por ende, de los censores. Los poetas del Grupo Cántico admiraron a los poetas de izquierdas que se han señalado, pero al mismo tiempo tuvieron unas excelentes relaciones con personajes afines a la dictadura. Buen ejemplo de ello es la presencia del catedrático Joaquín de Entrambasaguas (1904-1995) en varias revistas. Hay que señalar que Entrambasaguas tuvo mucho predicamento en el régimen, pues en 1939, vergibracia, estuvo a cargo en Valencia de la comisión que decidió la retirada de las resmas de papel, los cuadernillos aún sin coser, de El hombre acecha de Miguel Hernández.

Al inicio de la revista sexta de la primera época (agosto-

\footnotetext{
${ }^{7}$ Para demostrar cómo la censura prohibía la presencia de Cernuda en las revistas, registramos este texto que hemos hallado en el Archivo General de la Administración ("Libro de censura", signatura 5459) en su página 228, con fecha del día 10 de marzo de 1952, referente a Ínsula, comandando que sea omitido un fragmento alusivo al poeta sevillano contenido en el apartado "Las noticias y los ecos. Los premios Fastenrath y Álvarez Quintero" (que está recortado y pegado en el expediente). El siguiente párrafo aparece tachado en rojo: "El poeta español Luis Cernuda ha pronunciado en La Habana tres conferencias, que han versado sobre 'Orígenes de una generación poética: Litoral 1927', 'Unamuno como poeta' y 'Gustavo Adolfo Bécquer'. Después de una estancia en Méjico y Cuba, Luis Cernuda se ha incorporado a su cátedra de literatura española en Mount Hoyoak [sic] College (Massachusets, EE.UU)".

${ }^{8}$ Información disponible en el Archivo General de la Administración (inventario (03)049.001; signatura 21/1813).
} 
septiembre de 1948) luce una poesía de seis estrofas del mismo Joaquín de Entrambasaguas. Por estas fechas el historiador madrileño había creado también una imagen de profesor porque desde 1946 imparte clase en la Universidad de Madrid. El poema publicado en Cántico se articula en seis estrofas y se titula "Lo decisivo". La pieza gira en torno al tema de la muerte, tratada de forma abstracta, alude luego al proceso de descomposición del cuerpo y señala imágenes descarnadas como esta: "el cerebro sigue derramándose por la nariz". La primera estrofa es buena muestra de ello:

En ese instante, sólo en ese instante

que no se anuncia por ningún decreto estatal;

en ese instante tremendo,

es cuando se derrama el cerebro lentamente

y se vierte por la nariz

hasta que quedan abandonadas en el suelo tantas pobres ideas como frutos pasaos de olor agrio (83).

Los directores de Cántico no solamente dieron a Entrambasaguas un sitio preeminente sino que también le adornaron el poema con una ilustración de Miguel del Moral (1917-1998) — pintor del Grupo, junto a Ginés Liébana (nacido en 1921) - consistente en un ojo pleno de dolor sobre el que aparece una mano con un agujero atravesado por una flecha. El dibujo servía de cabecera contextual antes de la maquetación del nombre del poeta en letra mayúscula, tras el cual aparece el título del poema y la tirada lírica con treinta y cinco versos. Por tanto, la hoja inicial, vista con esta perspectiva, tenía una función no solamente de divulgación de un poema sino de empatía con Entrambasaguas. La relación entre el Grupo cordobés y el filólogo madrileño queda patente en la nota que él publica en la Revista de Literatura en 1954 titulada precisamente "Cántico reaparece", texto que celebra la nueva singladura de la revista al comienzo de su segunda época. Otro dato refrenda la buena relación entre la publicación y Entrambasaguas: su nombre está incluido entre los quince primeros "Suscriptores de honor" (98) que tuvo la revista, en el número

\footnotetext{
${ }^{9}$ Las citas de la revista Cántico se reproducen desde la edición facsimilar publicada en 2007, la cual está incluida en el apartado bibliográfico.
} 
séptimo de la primera época y en las seis siguientes entregas ${ }^{10}$.

\section{POESÍA INGLESA: FISURAS IDEOLÓGICAS SOLAPADAS DE SENTIMIENTOS}

La revista inaugural de la serie, publicada en octubre de 1947, abona nuestra hipótesis de trabajo al incluir al poeta británico W. H. Auden. Este escritor encarna a los poetas ingleses comprometidos políticamente de los años 30, al grupo de Oxford (Stephen Spender, Louis MacNeice, Cecil DayLewis, conocidos como "MacSpaunday") (Alexander, 2007: 363) cuya decantación poética de izquierdas era tan flagrantemente comprometida que provocó la reacción de otros escritores como Roy Campbell. Algunos de ellos visitaron España y apoyaron al bando republicano, en concreto Auden se alistó a las Brigadas Internacionales.

Auden llega a España en enero de 1937 para ayudar al bando republicano conduciendo ambulancias". Su poema "Spain", en suma, refleja fielmente su ideología. Este poema consta en Collected Poetry of W. H. Auden, publicado en América en 1945; en cambio, en la edición británica de 1966 (Collected Shorter Poems: 1927-1957) no figura dicha composición. Edward Mendelson, editor de la edición británica de 1976, llamaba la atención sobre las omisiones de la citada edición londinense con estas palabras: "Many of the early poems were further revised, and an alarming number were omitted" (1976: 12).

Lo cierto es que la revista Cántico contiene la siguiente pieza, en su versión española, traducida por J. Carandell Zurita. Su título es "Poema":

\footnotetext{
${ }^{10}$ Por tanto, Entrambasaguas consta en este listado de suscriptores la primera vez que aparece este apartado en la revista (en su número séptimo, 1948), así como: en su número octavo (114) (diciembre de 1948 y enero de 1949); después también está en el número inicial de la segunda época (abril de 1954) junto a otros nombres personales (157) e instituciones —estas figuran por primera vez ahora-, en el número segundo de esta nueva época (162) (junio-julio de 1954), en el tercero (186) (agosto-septiembre de 1954), en el cuarto (214) (octubre-noviembre de 1954) y, finalmente, en el quinto (242) (diciembre de 1954 y enero de 1955). En los siguientes números (el sexto, el séptimo, el octavo, el noveno y décimo - que es el doble dedicado a Luis Cernuda-, el undécimo y duodécimo, así como el último de la serie que es el décimo tercero) Entrambasaguas ya no consta entre los "Suscriptores de honor" (442).

${ }^{11}$ Para ahondar en la poesía inglesa sobre la Guerra Civil española, consúltese la tesis doctoral de Bernd Dietz, defendida en la Universidad de La Laguna, el 7 de junio de 1980 y publicada por el Servicio de Publicaciones de esa misma institución en 1985.
} 


\begin{abstract}
Deja amor mío reposar tu cabeza
sobre mi brazo desencantado;

el tiempo y sus febriles horas quema

toda belleza singular

de las criaturas pensativas

$y$ en el sepulcro se revela

cómo es efimera infancia.

pero abandónate a mis brazos

hasta que el día aclare, oh tú, ser palpitante,

ser mortal y culpable,

para mí bello, enteramente bello (9).
\end{abstract}

Se trata de una poesía lírica sobre al tópico del tempus fugit manifestado fundamentalmente en los versos tercero y séptimo, con evocaciones a la dama, la cual es la receptora ficcional del poema. El hecho de que los poetas de Cántico seleccionaran a Auden revela el interés del Grupo cordobés en este poeta renombrado. Ciertamente, los escritores a cargo de la selección del corpus traducido en la revista no optaron por el totémico "Spain". En primer lugar, consideramos que esta decisión responde a razones puramente estéticas, pues de hecho Cántico se aleja del contenido de revistas de perfil más explícito como la propia Espadaña, al igual que de Garcilaso. En segundo lugar argüimos que el hecho de no incluir el conocido poema es una forma de prevención respecto a la censura. Auden es un poeta heterodoxo cuyo aspecto temático, en el caso concreto del fragmento selecto, rompe con la voluntad de control de la censura. Por consiguiente, la muestra concreta de Auden colegimos que responde a razones estéticas al tiempo que refleja una fisura ideológica y una prueba fehaciente sobre la atención de los intelectuales a las ideas y a las estéticas europeas, en este caso inglesas, en comunión con la realidad circundante de España en esos momentos.

La mera inclusión de Auden en la revista publicada en España en octubre de 1947 denota el carácter heterodoxo del Grupo Cordobés en relación al régimen político del momento. El citado número fundacional también presenta un amplio poema del simbolista católico Paul Claudel — luego se aborda - y otra pieza de Oscar Lubics Milosz (1877-1939).

Por otra parte, hay que señalar la presencia en la tercera revista de 
Rupert Brooke (1887-1915), un poeta modernista ${ }^{12}$ cuyo legado refracta la I Guerra Mundial y sus consecuencias (Poplawski, 2008: 538). Constan dos sonetos de Brooke traducidos por José Luis Cano titulados "Mutabilidad" y "Nubes" (45). El primero es un soneto que el escritor inglés compuso en 1913, firmado en South Kensington-Makaweli. Fue publicado dos años después en el poemario The Collected Poems. El segundo se trata de otro soneto escrito en el Océano Pacífico también en 1913. Ambas ubicaciones locativas constan tras las traducciones antes del año de publicación del original. El primero versa sobre el paso del tiempo y aboga por un mundo ideal cuyos valores son "la Fe y la Bondad, la Sabiduría y la Verdad", según predica el verso tercero junto a una referencia explícita sobre la guerra al comienzo del segundo cuarteto:

Brilla siempre alli el sol de estas pálidas sombras, Junto a las inmortales banderas de nuestra guerra.

Y la gastada carne es ya pura belleza en una estrella, $Y$ los perecederos corazones, y el imperecedero amor... (45).

"Nubes" es una pieza meditativa donde la muerte es un índice temático expresado de modo explícito a comienzos del primer terceto: "Sabemos que los Muertos no mueren, viven eternamente / La rica herencia de su alegría y de su pena" (45). Este campo semántico está arropado por una imagen de oscuridad ${ }^{13}$ y de melancolía configurada en torno a los lexemas "noche", "nieve", "luna", "nubes" y "melancólica [...] cabalgata".

Es cierto que los directores de la revista Cántico, junto al traductor invitado, podrían haber elegido poemas todavía más signados por el tema de la guerra como es el caso de "The Soldier"14, otro soneto que refleja

\footnotetext{
${ }^{12}$ Conviene apostillar que el concepto de modernismo anglosajón es muy distinto al del ámbito hispánico, en tanto que fue un fenómeno coetáneo a las vanguardias continentales.

${ }^{13}$ Los poetas del Grupo Cántico eran conscientes de la experiencia de la Guerra, tal como registra Juan Bernier en su Diario el día 17 de julio de 1936: "Las ráfagas de los disparos sonaban largo rato, hasta que se hacía un silencio. Luego unos pocos tiros sonaban, intermitentes, tangibles; haciendo viajar a través de las ondas un eco de muerte, individual, detenida, anónima. Eran tiros de gracia”, añadiendo "[d]os meses ya. Los que caían eran amigos, hermanos, parientes, conocidos. Pero cada tiro llevaba un nombre, una interrogación angustiosa" (2011: 74).

${ }^{14}$ Este poema, "Soldado", fue publicado en 1946 en la revista tercera de la segunda época de Proel. Cuaderno de poesía (junto a otros dos: "Los muertos" y "El amor"), traducido también por José
} 
sinecdóquicamente la muerte de personas (soldados) anónimas durante la contienda bélica, cuyo contenido patriótico es mayor pero cuya explícita evocación del enfrentamiento bélico disonaría más en el statu quo de la España de postguerra. Pero también es cierto que tuvieron la osadía de incorporar a un escritor, Rupert Brooke, cuya poesía destila una temática de la guerra y cuya tópica encajaba en el ambiente de postguerra español del momento. De hecho, José Luis Cano escribe un párrafo escueto descriptivo en la última página de la revista a modo de presentación, enfatizando su participación "en la expedición naval de los Dardanelos" (46) así como su muerte en campaña el día 23 de abril de 1915. Nuestra conclusión abunda en la ya inferida a propósito de Auden: que los poetas de Cántico, lejos de desdeñar el tema y la realidad omnipresentes en la sociedad española de los años cuarenta, compaginaron unas composiciones en torno a la guerra que lograron esquivar la censura.

La misma presencia del algecireño José Luis Cano también conforma un aspecto elocuente digno de tener en cuenta en este trabajo, no solamente porque fuera cofundador de la revista Ínsula, sino también por su proximidad académica a escritores opuestos al régimen de Franco ${ }^{15}$. Cano entabló amistad con Luis Cernuda o Pablo Neruda durante su vida en Madrid en época de la República.

La configuración del microcosmos de pesadumbre, de lamento y de sufrimiento que estos dos poemas generan consideramos es una forma de sustanciar veladamente la queja de los poetas de Cántico, pues el receptor español del momento establecería una línea de contigüidad semántica entre las alusiones a la muerte de estos poemas y la propia Guerra Civil española. Así pues, la atmósfera generada por el significado de estos poemas, evocadora de la Guerra y de sus consecuencias, evitó el rechazo que suponía la censura.

Precisamente en la misma página donde están los dos sonetos de Rupert Brooke, la revista alberga en su mitad inferior un amplio poema del escritor francés Louis Aragon, quien era militante del Partido Comunista. Aragon, según escribe el propio Ricardo Molina, representa "la reacción desmedida contra todo género de poesía pura" a consecuencia de "las circunstancias impuestas por la última guerra en Francia" (46).

Luis Cano.

${ }^{15}$ Años después escribirá las biografías de García Lorca (1962) o de Antonio Machado (1975). 


\section{POESÍA FRANCESA: FISURAS DE COMPROMISO SOCIAL Y SU REVESTIMIENTO ESTÉTICO Y CATÓLICO}

El segundo número (diciembre de 1947) resalta la inclusión de André Gide, con sendos poemas traducidos y media página de crítica literaria presentadora del autor; también destaca en este número la presencia de la poeta portuguesa contemporánea Florbela Espanca (seis sonetos traducidos por Juan Bernier) cuyo refinamiento estético atrajo a los poetas cordobeses. En el tercer número (febrero de 1948) sobresale en este sentido la mencionada inclusión de Louis Aragon. Ya lo aseveró Fanny Rubio: que "[a]quí se empieza a hablar de los poetas franceses de la resistencia [...]" (2003a: 383).

André Gide ${ }^{16}$, según Ana González Salvador, es un "comunista de corazón" (1994: 1121) que llegó a militar en el socialismo. A Cántico le interesa Gide como prosista y como poeta. La selección abarca dos páginas enfrentadas. En primer lugar, se lee el extracto en prosa titulado "Nathanael, no hemos mirado", seguido por dos poemas breves cuales son "El parque" y "La paloma", así como por el párrafo en prosa "Biska - Al atardecer" (26). La segunda página comienza con la traducción "Hylas cantaba...", seguida por los poemas "Ronda de Granada" y "Octubre", para terminar con "No! No he contado aún" (27).

El poeta traductor, Ricardo Molina, dedica un artículo de siete párrafos al simbolista francés en la sección final de la revista. Bajo la cabecera "André Gide: Premio Nobel 1947”, Molina comienza aludiendo al "puesto excepcional que hoy ocupa Gide en las letras europeas" (30) por lo que corroboramos que el seleccionador del corpus a traducir y el traductor — que en este caso es la misma persona - estaba atento a las

\footnotetext{
${ }^{16}$ La censura señaló a Gide. Hemos hallado, en relación a Ínsula, el siguiente informe de "Inspección de Revistas" fechado el 28 de febrero de 1949 cuya información se refiere a la entrega trigésimonovena: "Este número atiende más directa y exactamente a temas y figuras españolas si bien más o menos dentro de la orientación habitual. La página segunda está dedicada en su mayor parte a las conferencias del Aula de Humanidades de Ortega y Gasset. La actitud frente a Ortega es de completa adhesión a su figura y a sus doctrinas. La página tercera dedica toda una columna a ensalzar un pretendido movimiento de 'Inteligentsia' de intelectuales europeos y americanos de signo internacional, acaso masónico y desde luego laico. Todos los intelectuales citados en el artículo son o anticatólicos o no significados como católicos: Einstein, Sartre, Gide, Wright, etc." (Documento consultado en el Archivo General de la Administración, en el inventario (03)049.001).
} 
modas y a las novedades francesas.

Es elocuente que Ricardo Molina asevere que "[h]asta hoy se ha señalado con preferencia la 'parte del Diablo' (muy dilatada en la producción gideana); la 'parte de Dios', en cambio, está casi por descubrir" (30). El traductor y crítico cordobés subraya el "denouèment", "sinceridad" o "desnudamiento estilístico" a cuya luz debe estudiarse la obra de Gide. Ricardo Molina afirma que está interesado en Les Cahiers d'André Walter, en Les Nourritures Terrestres y en Les Nouvelles Norritures, "tres libros a través de los cuales nos ha transmitido el más seductor e inaceptable de los mensajes sobre la vida, el amor, la felicidad" (30).

A la revista Cántico, al menos según postula su fundador, no le interesa el Gide comprometido de la poesía rebelde; tampoco la poesía del conflicto íntimo sobre su identidad sexual — vertiente que influenció a Cernuda (Barón, 1994: 123)—. Le interesa el Gide que busca la salvación y la trascendencia del ser humano. En este sentido, conviene subrayar que la estética del Grupo Cántico, opuesta a la poesía tremendista de Espadaña, no comulga con la mencionada poesía social ${ }^{17}$. En cualquier caso, subrayamos que Molina optó por esta nómina de poetas, aunque, por razones obvias de autocensura, incluyese unos poemas que no le llevaran al señalamiento político. Consideramos que los poetas del Grupo Cántico no quedaron indiferentes tras la revolución poética que supuso la publicación de Hijos de la ira o de Sombra del paraíso, de Dámaso Alonso y de Vicente Aleixandre respectivamente en 1944, en un año revolucionario según lo ha conceptualizado Víctor García de la Concha (1973: 293, 1987: 490) y según lo han subrayado después numerosos críticos como Eleanor Wright (1986: 36).

Si Gide es un poeta de izquierdas, el siguiente francés que la revista Cántico presenta también lo es. Louis Aragon ${ }^{18}$ se alista al Partido Comunista (Bouiller, 1985: 302) llegando a ser "un comunista fidelísimo, contra viento y marea" (Pujol, 1976: 139). La propia elección e inclusión de

\footnotetext{
${ }^{17}$ Señalemos que Molina escribe un libro titulado Función social de la poesía, publicado póstumamente, donde cartografía desde la "era preliteraria" hasta la "edad moderna" deteniéndose - solamente en el tramo final del volumen- en el concepto del poeta como "cantor social" involucrado en una "actitud política" (1971: 229).

${ }^{18}$ Louis Aragon está presente en el número quinto de Entregas de poesía, que data de mayo de 1944. También se lee en Aglae (otra revista cordobesa, en este caso dirigida por Manuel Álvarez Ortega) en el número segundo, que data de octubre de 1949, con "La primavera" y "Zona libre".
} 
Aragon, en la revista publicada en octubre de 1948 (en el tercer número de la serie), en pleno franquismo, es un hecho significativo que no debe pasar inadvertido al estudioso. El poema traducido es "Noche del destierro"19 el cual se articula en 58 versos. El traductor es Ricardo Molina y las dos primeras estrofas de su texto se registran seguidamente:

Qué importa al desterrado que mientan los colores

Se juraría - dice-que es París

De no rehusar la fe en las apariciones

Yo escucho los violines preludiar en la fosa.

Es la Ópera — dice- ese fuego cambiante

Cómo hubiera querido retener en mis ojos

Balcones encendidos bronces tejados verdes

Esa esmeralda muerta y esa piel plateada (45).

En este caso, el poema porta cierto contenido político revestido de referencias al encuentro de los enamorados y al amor. El fragmento trata el tema del destierro con alusiones a la muerte a través de significantes como "fosa", "esmeralda muerta", "noches", "negras pupilas de las palomas", "sombra", "sueños a la deriva" y "la noche [...] que no tiene mañana" (45).

Igual que ocurre en el caso de André Gide, Ricardo Molina se preocupa de integrar un texto crítico en la sección final de la revista, donde lo denomina abiertamente "poeta de la resistencia" e incluso compara su poesía "con la de nuestro Lorca" (46). La poética de Aragon encarna "la reacción decidida de todo género de poesía pura" (46) como consecuencia de "la última guerra en Francia". El poeta y traductor confirma que el "frío, el hambre, la muerte, y los horrores de la guerra compartidos por los poetas han establecido una comunicación más íntima entre estos y el pueblo. El poeta se vio obligado a abandonar sus preocupaciones 'lujosas' atenazado por las circunstancias" (46). Que esto lo diga Ricardo Molina en la España de postguerra, en enero del 48 , no puede pasar desapercibido ya que la censura operaba de manera contundente y, a pesar de ello, Ricardo Molina escribía y publicaba esto en una revista cuyo pórtico viene de la mano de Vicente Aleixandre con su "Carta a los fundadores de Cántico" (35).

${ }^{19}$ El poema francés es "La nuit de l'exil" y consta en el libro Les yeux d'Elsa. 
Otro aspecto - en este caso no consideramos que fuese ideado ad hoc para evitar la censura - es la presencia de otros temas de índole amorosa o religiosa, asuntos que Guillermo Carnero resalta como centrales en el legado de Ricardo Molina. Carnero establece que la "religiosidad" en el caso de Ricardo Molina ${ }^{20}$ "parece genuina [...] cuya fuente literaria se halla en la obra de poetas como Pierre Emmanuel, Charles Péguy, Paul Claudel y Francis James, que Ricardo Molina apreciaba en grado sumo, y en ocasiones tradujo" (2009: 82). De hecho, ese número alberga además veinticinco poemas cuya temática es lírica como "Abrazo" (37) del propio Molina o "Encuentro del antiguo amor" (Roque Esteban Scarpa), descriptiva y evocadora del paisaje como "Sierra" de Juan Bernier, "Canción de la puerta de Triana" (Rafael Montesinos), "Córdoba" (Miguel Molina Campuzano), "Poema” de Pablo García Baena, o religiosa como "Señor, Señor" (Juan Valencia) y "Oración" (Juan Ruiz Peña). Es sintomático que el poema "A la luna", del gaditano Pedro Pérez-Clotet contenga tras el título y el primer verso la leyenda: "Con licencia"21 en un paréntesis con letra más pequeña.

Se concluye que el poema de Louis Aragon, traducido por Ricardo Molina, trata explícitamente temas políticos, en particular anclados en la postguerra francesa, cuya aplicación — mutatis mutandis - al panorama español podría hacerlo el receptor empírico del mismo con facilidad. El hecho de que trate de la contienda francesa, y no de la española, coadyuvaría a sortear la censura, junto al contexto de poesía religiosa, amorosa o descriptiva que eclosiona en la propia revista. Ahora bien, el predominio de temas reflexivos, introspectivos con referencias a la "luna", a la "noche" o al "otoño" entre otros, configura un ambiente lúgubre y de decaimiento de manera explícita.

El número cuarto de la revista amplía la nómina de poetas de

\footnotetext{
${ }^{20}$ El propio Ricardo Molina escribe en su Diario lo siguiente el día 2 de enero de 1943: "Quiero [...] realizar en mí el ideal católico, único verdadero ideal de salvación; convertirme en un foco de irradiación del cristianismo, manantial imperceptible, sin programa; dejar correr las ondas de gracia que pido a Dios diariamente sobre aquellos que me rodean; desbordarla que es signo de poseerla [...]" (1990: 41).

${ }^{21}$ Pedro Pérez-Clotet, compañero de colegio de Rafael Alberti, alumno en la universidad de Pedro Salinas y compañero de Luis Cernuda, perteneció — sin embargo - al Movimiento Nacional; por lo que la referencia "Con licencia" respondería al poema sobre el desarraigo, la pérdida de los sueños, el "gemido" (39) y la queja que desprende la pieza.
} 
izquierdas que venimos estudiando a través de la inclusión de Charles Péguy. Este escritor galo — según aduce Carlos Pujol— es "el único campesino auténtico de la literatura francesa" (1976: 136). El origen humilde de su familia y su periplo estudiantil - que pudo tener gracias a las becas - remarca su predilección por los más desfavorecidos socialmente.

Ciertamente, los fragmentos de Péguy que Ricardo Molina traduce son de carácter religioso y encarnan un epítome de su obra de la que el poeta de Cántico afirma "que es sobre todo un documento religioso" (62). En palabras del traductor, la obra de Péguy es "el más ferviente e inspirado monumento religioso de la literatura francesa" donde relumbran rótulos tales como Le Mystére de la Charité de Jeanne d'Arc, Le Mystére des Saints Innocents o Tapisseries. Molina incluso llega a lamentar "la indiferencia religiosa de nuestra época" (62).

En este caso, Ricardo Molina no alude a su poesía de raíces también socialistas ni a su concepción libre del catolicismo basada en un humanismo cristiano en pos de la justicia social. Lo cierto es que el socialista católico de Orleans ocupa una página de la publicación española. En primer lugar, consta un fragmento titulado "Eucaristía", seguido del poema "El llanto de la Virgen" antes de "Singular misterio"22. De nuevo, Ricardo Molina escribe una breve semblanza crítica del escritor foráneo que se lee en la parte final de la revista, en este caso titulada "Charles Péguy, poeta de la pasión" (62), de la que hemos citado algunas ideas en los párrafos precedentes.

La conclusión que se desprende del caso de Péguy es que el comentario, la traducción y la publicación de poesía religiosa actúan como material liberador de otros temas que la censura no permitía. La inclusión del autor francés está acompañada de un número netamente religioso (número cuarto, abril de 1848) desde la misma portada que luce un poema titulado "Al Santísimo Sacramento" (compuesto por Antonio de Solís), la primera página que contiene una imagen de Jesucristo dibujada por Ginés

\footnotetext{
${ }^{22} \mathrm{La}$ sobresaliente presencia de poesía religiosa, ya se ha mencionado, fue un parámetro a favor de Cántico en términos censorios. A modo de ilustración registramos esta información referida al laicismo que el censor apreciaba en el número cuadragésimo quinto de Ínsula: "Sigue teniendo ese indefectible pero imborrable tufillo de asepsia de todo lo laico, y la preferencia por todo lo extranjero o por lo español que se parezca a lo extranjero en el laicismo cultural", fechada el 25 de noviembre de 1949 (consultado en el dossier "Inspección de revistas" del mencionado inventario en el Archivo General de la Administración).
} 
Liébana precediendo al poema "Paso de Dios (de José A. Muñoz-Rojas), hasta "Miércoles de Ceniza" de Pablo García Baena, "Salmos" de Ricardo Molina, "Ella reza" de Pierre Emmanuel y terminando con las tres piezas de Péguy. Por lo tanto, sin deplorar la decantación religiosa de Molina, la elección de esta temática religiosa en dicho número cabría interpretarla también como un mecanismo para esquivar la censura en España, toda vez que el poeta elegido no iba a ser bien recibido a priori por los responsables de autorizar las obras.

Volviendo al número primero, hallamos al mencionado Paul Claudel $^{23}$ (1868-1955), cuyas creencias católicas son destacadas por los estudiosos (Desaintghislain et alii, 1995: 420). Igual que Péguy, Claudel cultiva el versículo lo cual influye sobremanera en la prosodia de los escritores del Grupo Cántico. Un amplio fragmento, basado en la Creación y en la espiritualidad (Velázquez, 1994: 1191), es la pieza traducida por Ricardo Molina titulada "El espíritu y el agua" cuyo comienzo genera un diálogo entre el sujeto lírico y Dios Creador:

Dios mío que separasteis las aguas inferiores de las aguas superiores, mi corazón gime hacia Vos, libertadme de mí mismo por ser Vos quien sois.

¿Para qué quiero esa libertad y qué tengo que hacer en otra parte. Yo necesito sosteneros.

Yo veo, Dios mio, el hombre perfecto, perfecto en el perfecto Árbol Vuestro Hijo [...] (12).

Paul Claudel es otro claro exponente de la poesía sagrada en la revista Cántico la cual, sin faltar los motivos religiosos en los demás números, emana de forma pronunciada en la entrega que cierra la primera época (diciembre de 1948 - enero de 1949, número octavo) que está porticada por un dibujo mariano, o en el número quinto de la segunda época (diciembre de 1954 - enero de 1955) que es una entrega dedicada por completo a la Virgen María y cuya portada contiene un dibujo de Nuestra Señora de la Fuensanta.

\footnotetext{
${ }^{23}$ Es destacable la presencia de traducciones de Claudel en otras revistas del momento: en el número vigésimo primero de Escorial, en el número trigésimo tercero de Garcilaso, en el número primero de Espadaña, en el número tercero de la segunda época de Proel. Cuaderno de poesía o en el número octavo de Verbo. Cuadernos Literarios.
} 
Por tanto, inferimos que el contenido religioso, aunque conste adyacente a otros poetas comprometidos, ubicados ideológicamente en el bando contrario a la dictadura, es predominante en la serie de Cántico en ambas épocas, y - aunque sus directores quisieran compartir y recrear un valor sincero estético y artístico también - no podemos desdeñar el buen encaje de esta tapicería temática con los preceptos de los censores. Una conveniencia y connivencia similar se vislumbra en el poeta italiano tratado a continuación.

\section{LA TRADUCCIÓN DE POESÍA ITALIANA: FISURAS PATRIÓTICAS Y HERMETISMO}

Destaca en el número cuarto de la nueva época (octubre-noviembre de 1954) la presencia de Giuseppe Ungaretti. Antes de proseguir conviene leer la opinión de Eugenio Montale ${ }^{24}$ sobre su colega generacional: “[...] Hai visto la poesia mussoliniana di Ungaretti? L'altra — Levante - è buona. Ma perchè scriverci: 1914? [...]" (1981: 9). Margarita Garbisu ${ }^{25}$ descarta que Ungaretti perteneciera directamente a la doctrina fascista, sin embargo, confirma "el carácter belicista" y la "fuerte exaltación patriótica" del poeta $(2002: 59,120)$.

La cuestión es que la imagen sociopolítica de Ungaretti no desentonaba en la España franquista y su inclusión en la revista estimamos que, además de responder a las motivaciones estéticas importadoras y renovadoras de los escritores cordobeses, respondería también a motivos políticos. Fiel ejemplo es la siguiente proclama - escrita por el poeta en Il Popolo d'Italia en febrero de 1919- que ensalza a la patria, como un componente intrínseco de la persona y en la que defiende las consecuencias de la guerra amparándose en la justicia que los individuos deben mantener para preservar así el orden y la armonía sociales:

[...] Ma due cose sono certe: la patria è una cosa che portiamo nel sangue, che è viva e indispensabile in noi come il cuore; e dalla

\footnotetext{
${ }^{24}$ Consta en una carta enviada por Montale a Quasimodo (de estos dos poetas también figura un poema de cada uno en la misma revista).

${ }^{25}$ También lo recoge la profesora en su libro. Ungaretti deja por escrito sus alabanzas a Mussolini, tal como se lee en esta carta dirigida a Papini: "[...] Mussolini mi ha affidata la corrispondenza el 'Popolo' al Congreso ella pace. Amo il giornale di Mussolini [...]” (en Garbisu, 2002: 123).
} 
guerra è nata una visione della giustizia sociale, che dobbiamo sforzarci di distinguere e attuare, se non vogliamo perire di bestialità e d'inedia. Bisogna mettere la patria all'ordine del giorno. Patrie e rivoluzione; ecco il grido nuovo (en Garbisu, 2002: 122).

La distribución y el planteamiento del poeta no puede dejar indiferente al crítico: está en la misma portadilla de la revista, tras la cartulina de portada; además, el diseño de su nombre figura con una tipografía mayúscula, voluminosa y centrada. Es más, la emergencia de Ungaretti en el pórtico de Cántico consideramos que es una especie de tarjeta de presentación para obtener la anuencia, el beneplácito y la simpatía de los censores del momento.

El primer poema es "La morte meditata" y proviene del poemario Sentimento del tempo (1933). El segundo poema se titula "Tutto ho perduto" y procede de Il dolore (1947). El primero está en la página de cabecera - como se ha dicho- (215), en tanto que el segundo está al comienzo de la segunda página de la publicación (216). En ambos casos figura una traducción aledaña realizada por Ricardo Molina. Aquí está la versión española del fragmento de "La morte meditata":

Has cerrado los ojos.

Nace una noche

llena de simas engañosas,

de sones muertos,

igual que corchos

de redes sumergidas en el agua.

Tus manos se han vuelto un soplo

de inviolables distancias,

inasibles como la idea,

y lo dudoso e indeciso

de la luna - dulcísimos-

con ellas me rozas los ojos

tocan el alma.

La dama eres que pasa 
tal una hoja.

Y en los árboles dejas fuego de otoño (215).

Estos poemas no versan sobre la guerra de forma directa, pero, ciertamente, ambas piezas rezuman dolor y sentimiento trágico, derivados naturalmente de su experiencia bélica y de "su contacto directo con el desastre humano" que "provocan la creación de muchos poemas" (Garbisu, 2002: 120-121). La destinataria ficcional del primer poema es una dama; el segundo es un canto nostálgico por la infancia perdida donde late la desesperación del ego poético. Por lo tanto, el contenido engarza con el contexto del momento de la revista cordobesa en lo que atañe al espíritu de la postguerra mientras que la propia elección de este poeta supondría la venia de los censores.

Lo mismo se aprecia en el poema incluido de Eugenio Montale (1896-1981) en cuestión temática. La pieza se titula "L'Anguila" (233) y es buen espécimen del hermetismo cultivado por estos italianos que revela "cuanto [Montale] ha experimentado y sufrido" (Anaya, 1989: 76) y encarna una consciencia colectiva (Dombroski, 2004: 505). En este caso hay que señalar que Montale es un poeta marcadamente antifascista conocedor de la experiencia de la guerra y de la postguerra en su país (Dombroski, 2004: 506). Lo mismo aplicamos a Salvatore Quasimodo (1901-1968) quien también consta con la composición "Quasi un madrigale" (234). En este caso, además destaca para nuestro propósito su disonancia ideológica respecto a Ungaretti, y también respecto al régimen español, pues Quasimodo era cercano al Partido Comunista al que incluso estuvo afiliado durante un tiempo.

La escritura hermética se entiende como un mecanismo de compensación respecto a la libertad suprimida que cuadra en el contexto español, al menos, como herramienta retórica. Según escribe Sergio Solmi, el hermetismo refleja "[1]a libertad suprimida pero insuprimible" al tiempo que "parecía instintivamente una sutil y secreta escapatoria en la obra aislada, y se configuraba ante todo en la prioritaria y esencial moralidad de la forma" (en Petronio, 1990: 940). La presencia contundente de estos poetas italianos, así como la disposición mediante la que está diseñada la maquetación del número, con la destacada emergencia de Ungaretti en la cabecera, consideramos que responde a la aplicación de cierta dosis de 
autocensura en aras de lograr la aquiescencia del establishment, aunque también estimamos que evidencia el interés de Ricardo Molina por plantear y difundir novedades poéticas en España desde su revista.

\section{POESÍA GALLEGA Y CATALANA: FISURAS DE OTRAS LENGUAS PENINSULARES}

La abundante presencia de poesía de las lenguas peninsulares catalana y gallega es otro elemento digno de estudio para los intereses de este trabajo. Jordi Gracia afirma que "la literatura catalana fue objeto de un secuestro implacable durante las dos primeras décadas de la España de Franco", aludiendo incluso a un "hostigamiento primario a las lenguas autóctonas [que] actuó con pretextos ideológicos-históricos heredados de una vocación unitarista [...]" (1993: 90). Una década después, Jordi Amat asevera que al "terminar la Guerra Civil, el nuevo régimen legisla contra la lengua catalana” (2003b: 28). Así, la Delegación Nacional de Prensa, Propaganda y Radio promulgó, entre sus normas y principios, que el catalán estuviera limitado a la vida familiar. La censura era implacable con las lenguas peninsulares, especialmente con el catalán (Gallofré, 1989 y 1991). Massot y Muntaner señalan que en los años cuarenta la posibilidad de que un texto catalán fuese autorizado por la censura era impensable (en de Blas, 2007). Josep Benet alude a "la persecución contra el uso público de las lenguas de las nacionalidades minoritarias" (Benet, 1985: 101). Respecto al gallego, Basilio Losada concluía que "ante la imposibilidad de desarraigarla [...] tenían especial interés en impedir su consolidación como lengua de cultura, prohibiendo la traducción al gallego de textos de otras lenguas [...] (en de Blas, 2007). Sin embargo, el mandato de Joaquín Ruiz-Giménez como Ministro de Educación Nacional (1951-1956) "estuvo marcado por un pragmático sentido de la tolerancia" (Gracia, 1993: 92-93). Con este panorama normativo y regulador hay que enfatizar el elocuente hecho de que la revista abrace poesías en esas lenguas peninsulares.

Cántico publica literatura catalana y gallega lo cual revela su carácter integrador frente a quienes abogaban por el "resistencialismo" (Amat, 2007: 162). Esta decisión de integración encarna lo que Jordi Amat denomina el "Espíritu de Segovia" o el "diálogo por la concordia" (2007: 
161), específicamente porque este punto de inflexión ${ }^{26}$ eclosiona en el primer Congreso ${ }^{27}$ de Poesía celebrado en Segovia ${ }^{28}$ del 17 al 24 de junio de $1952^{29}$. Amat apostilla que "durante los tres Congresos de Poesía [...] este diálogo tuvo su manifestación más evidente, pero en otros espacios [...] se desarrolló también un ambiente favorable para que la literatura catalana saltara las barreras que le habían sido impuestas desde el final de la guerra civil" (2003a: 3). Estimamos que la revista Cántico es un epítome de esos espacios tal como evidencian las muestras siguientes.

Con estos prolegómenos, se corrobora que la inclusión de los autores gallegos y catalanes en la revista Cántico encaja en un fenómeno más amplio, propio de la década de los cincuenta. El primer número de la segunda época, publicado en abril de 1954, contiene dos poemas en catalán de Joan Vinyoli (1914-1984), titulados "Gall" y "El callet", traducidos por él mismo con los títulos de "Gallo" y "El silente" (136137), en los que predomina una línea temática meditativa con un lamento soterrado en espera de la esperanza. El primer poema rotura la temática del grito y de la queja que la revista en ocasiones contiene de manera implícita, puesto que el gallo "es el animal que rompe su silencio con su grito" anunciando "desde la oscuridad la llegada de la aurora y de la luz", tal como ha estudiado Ferran Carbó Aguilar (2006: 68). Las dos primeras

\footnotetext{
${ }^{26}$ Establece Jordi Amat que "[d] esde el fin de la guerra no se había producido un debate de tanta trascendencia sobre el encaje de Cataluña en España. [...] Pero ahora se había dado un paso adelante porque por primera vez desde el 39 la dialéctica no se planteaba entre vencedores y vencidos, sino entre 'comprensivos' y 'excluyentes'” (2007: 174).

${ }^{27}$ Tras el primer Congreso de Poesía (Segovia, 1952), tiene lugar el segundo celebrado en Salamanca en 1953 y, después, el tercero cuya sede es Santiago de Compostela en 1954.

28 Albert Manent confirma que en el Congreso de Segovia "brillaron Carles Riba y Dionisio Ridruejo, quienes fueron los adalides del diálogo entre ambas literaturas" (2003: 7). Por otra parte, Jaime Medina señala que Rafael Santos Torroella (quien idea el Congreso) "animaba a Riba a romper el aislamiento en que se encontraban los escritores catalanes, yendo a dar testimonio a Segovia del estado viviente de su fecunda literatura", añadiendo que este Congreso "contribuyó notablemente a hacer salir a la literatura catalana de la precariedad en que se encontraba [...] se dio un empuje importante a su expansión" (2003: 16).

${ }^{29}$ Carles Riba y Eugeni d'Ors abordaron este asunto en sus conferencias. Riba diserta el 18 de junio por la tarde sobre "Un siglo de renacimiento literario en Cataluña". Amat concluye que "el diálogo fue en esencia: voluntad de conocimiento de la literatura catalana y asunción de que durante una década se había perseguido injustamente una literatura que formaba parte del patrimonio cultural común. Aunque algunos lo sabían -Aleixandre y Cano, Ridruejo o Tovar-, la mayoría de congresistas descubrieron en Segovia que la literatura catalana no era una manifestación provinciana ni mero folklore" (2007: 165).
} 
estrofas lo objetivan así:

Gallo encumbrado en la torre más alta, deme aqui en el confin de la noche y la aurora. En la noche del tiempo llama siempre tu canto.

Tiempo difunto, difunto, te veo río que se alarga en la sombra. Huésped soy de la tierra, inexperto, exiliado dentro de mí, que mira correr las aguas intramuros de la ciudad abandonada (136-137).

Este mismo número incorpora otros dos poemas en catalán y en español que son escritos por Joan Perucho (1920-2003): "Epitafi per a un almirall, a la manera antig" y "El médium", el cual además rotula el título del libro publicado en 1954 - el mismo año de la edición del número de la revista- . La tópica de estas piezas en torno a la muerte confirma la estela temática que los poetas directores quieren imprimir a su revista. La segunda estrofa de "Epitafio para un almirante, a la manera antigua" es la siguiente:

Triste pequeño cementerio

de la tierra natal tan ennoblecida:

Apenas la yerba crece entre las tumbas.

El viento te ronda tristemente, este viento obstinado del otoño (140).

El segundo número de la nueva época, publicado en junio-julio de 1954, presenta dos poemas en versión bilingüe autotraducidos por Joan Triadú (1921-2010) ("Pareu-hi esment" y "Ruines"; "Poned atención” y "Ruinas", 172), cuidadosamente dispuestos en forma contigua de modo que el lector pueda elegir qué versión aprehender e incluso compararlas fácilmente. La semántica de las piezas evidencia lo antedicho en cuanto al clima de postguerra, no solamente por el título explícito del segundo poema sino también por la tercera estrofa del primero: 


\section{Así vuestro país}

perderá su color. La mancha

era un estorbo infeliz

de mi grandeza (172).

El número tercero (agosto-septiembre de 1954) comienza con un poema en catalán de Carles Riba (1893-1959) titulado "Dins la nit..." dispuesto en la primera página de la revista de manera monolingüe. Detrás, en la segunda página, consta la traducción. En este caso los poetas de Cántico no optaron por diseñar los versos de manera paralela por lo que al abrir la portada el receptor se encontraba con una veintena de versos en catalán. El poema introspecciona sobre la fugacidad del tiempo añorando los años pasados, profiriendo sendas preguntas retóricas al "niño que fui” (188). La inclusión de Riba en la revista colegimos que partió del encuentro de los poetas cordobeses con el barcelonés en el tercer Congreso de Poesía que tuvo lugar en Santiago de Compostela del 21 al 27 de julio de ese mismo año bajo la presidencia de Menéndez Pidal. Olga Rendón postula que allí "los andaluces entablaron amistad personal con jóvenes promesas gallegas y catalanas" concluyendo que "[e]ste acercamiento personal propició, en gran medida, la aparición [en Cántico] de poemas bilingües de estas regiones" (2017: 75).

Precisamente en este número, fechado en agosto-septiembre de 1954, destaca la "Carta sobre la actual poesía gallega", escrita por Álvaro Cunqueiro quien señalaba la aportación de dicha lírica al conjunto de poesía en español, así como la complementariedad existente entre ambas literaturas:

Quizá nosotros, los poetas gallegos, pongamos en el conjunto de la poesía hispánica, una nota más íntima y subjetiva, acentos de un apasionado amor al paisaje nativo, la gracia arcaica de algún tema o alguna forma, y una sombra de vaga melancolía, que acostumbramos a llamar saudade. Parece alguna vez como si cantáramos desde muy lejos, desde una isla verde como un trébol, navegante entre la niebla y el mar (197).

Tras la página teórica, destacan seis poemas gallegos autotraducidos cuyos autores son Aquilino Iglesia Alvariño (1901-1961) ("Dous mil anos 
de Tibulo", "Dos mil años de Tibulo"), el mismo Álvaro Cunqueiro (19111981) ("Os catro chefes de casa de Gingiz", "Los cuatro jefes de la casa de Gingiz"), Eugenio o Uxío Novoneyra (1930-1999) — destacó por su activismo político- ("Letania dos tesos cumes", "Letanía de las poderosas cumbres"), Manuel Antonio (1900-1930) ("Os cóbados no barandal", "De codos en la baranda"), Xosé Díaz Jácome (1910-1998) ("Namoro", "Noviazgo") y Manuel María (1929-2004) ("Cousa sin nome", "Cosa sin nombre") quien estaba comprometido políticamente llegando incluso a participar de manera clandestina en la organización de los partidos nacionalistas.

La selección de poemas gallegos y sus traducciones está presentada mediante el sintagma nominal impreso en letra mayúscula "Poesía gallega contemporánea", centrado entre las dos páginas con un diseño bien meditado. El título está seguido - también a caballo entre las dos páginas - por esta apostilla: "Cántico dedica estas páginas de poesía gallega conmemorativas del III Congreso de Poesía en Compostela al Iltmo. Sr. Director General de Enseñanza Universitaria don Joaquín Pérez Villanueva ${ }^{306 ،}(198-199)$.

Hacia octubre-noviembre de 1954 la revista Cántico incorpora un poema en catalán de quince estrofas precediendo a la versión española del mismo. Albert Manent (1930-2014) es el poeta autotraductor invitado y el poema elegido es "Faula de la Italia somniada", el cual es un tributo a un destacado catalanista según reza al comienzo: "Homenaje a Guerau de Liost" (226). Hay que añadir que Manent participó en la actividad cultural clandestina durante la dictadura, asistiendo a las clases de catalán organizadas por Joan Triadú así como a lecturas poéticas.

Estas publicaciones de poesía catalana y gallega en Cántico las interpretamos como una muestra del agrietamiento que tuvo el monolítico discurso en pro del español a mediados de los años cuarenta y a comienzos de los cincuenta. La mera elección lingüística y estética de literatura en lenguas peninsulares atentaba contra la retórica del régimen y contra su nacionalismo extremo. Hemos de señalar que esta corriente cultural se había hecho patente en las hojas de Cántico, de la misma manera que era tangible, en Ínsula y, entre otras revistas, en la Gaceta Literaria

${ }^{30}$ Esta dedicatoria la interpretamos como otra muestra de la búsqueda de la quiescencia por parte del régimen. 
donde Tomàs Garcés y Juan Chabás coordinaron una sección dedicada a la literatura catalana (Amat, 2007: 165). De esta forma, según investiga Jordi Amat (2007: 162) se objetiva una transición ${ }^{31}$ desde la "cultura de la resistencia" hacia una "cultura de la presencia", mediante un "diálogo" y una "voluntad de conocimiento". Con estas premisas, se concluye que Cántico converge en la nueva corriente cultural integradora y tolerante con las letras catalanas que Jordi Gracia conceptualiza en su artículo titulado "Los años cincuenta y la vía española de un catalanismo cultural" en la que se pasa de "una vida intelectual necesariamente hibernada" hacia "la vitalidad crítica de una cultura" (Gracia, 1993: 112).

La impresión de poemas en catalán y en gallego, aunque acompañados de sus correspondientes traducciones al español, testifica el carácter de la revista cordobesa, atento al ámbito internacional y también a otras lenguas nacionales. Asimismo, según se ha anotado, algunos de los escritores gallegos o catalanes participantes en la revista se distinguieron por su activismo cultural y por su actividad política clandestina.

\section{CONCLUSIONES}

Se concluye que la militancia política de algunos de los poetas traducidos en la revista Cántico se encuentra en el socialismo e incluso en el comunismo, como demuestran Louis Aragon, André Guide, Charles Péguy, Salvatore Quasimodo y W. H. Auden. En el caso del inglés se constata incluso su pertenencia al bando republicano de la Guerra Civil española. Ahora bien, los poemas seleccionados no atentaban contra el orden moral ni contra el orden político, por lo que no aportaban motivos explícitos para ser censurados. Junto a estas inserciones de carácter internacional, cuya presencia disuena respecto a la línea editorial de la dictadura, destaca el elenco de poemas catalanes y gallegos cuya mera presencia en estas revistas de postguerra consideramos que también supone un desafío a los valores de la lengua nacional.

Por consiguiente, el afán aperturista de la revista se ratifica mediante la inclusión de voces catalanas y gallegas, gracias a un conjunto

\footnotetext{
${ }^{31}$ En el primer Congreso de Poesía se expresan algunas "sugerencias para el diálogo"; Carles Riba defiende "la poesía en lengua catalana, como obligada por una razón íntima y familiar" (Amat, 2007: 145).
} 
de poemas catalanes y gracias a un grupo de poesías gallegas adjuntas a un artículo presentador, cimentando y consolidando así una nueva dinámica cultural integradora - frente al aislacionismo y frente a la resistenciaque constatamos propia de la década de los cincuenta.

Además de las conclusiones sobre las poesías clasificadas por lenguas, queremos siquiera mencionar la importancia que tiene la presencia de Federico García Lorca ${ }^{32}$ y la concluyente presencia de Luis Cernuda, precisamente en un doble número que los poetas de Cántico (números 9 y 10, agosto-noviembre de 1955) le tributan como homenaje. Este asunto no es cuestión baladí porque refrenda el riesgo, la gallardía consciente y la autoafirmación ecléctica de los poetas cordobeses al dispensar un espacio notable a escritores proscritos en la España del momento, pero cuyo mérito literario merecía su atención.

Frente a estas muestras de carácter disonante con el régimen se acompasa otra nómina de creadores cuyos nombres son afines al poder establecido como es el caso de Joaquín de Entrambasaguas o de José María Pemán. Por tanto, hay que postular también que las relaciones literarias y extraliterarias mantenidas por los miembros de Cántico con otras personas vinculadas a la censura, como es el caso de Entrambasaguas, coadyuvaron a la mirada complaciente que tuvo la revista cordobesa por parte de los informadores locales y, por ende, por parte de los órganos censores.

Dentro de esta argumentación señalamos la inclusión de Ungaretti, cercano al fascismo italiano, cuya diseñada ubicación en la página primera de una revista estimamos que responde a cuestiones estéticas pero también a asuntos políticos de autocensura. Se deduce que la revista contiene una clara autocensura hecha tangible en la disposición de los poetas con sus composiciones y en la misma selección del corpus publicado. Por inocente que parezca la dispositio de los mismos, se vislumbra un plan premeditado

\footnotetext{
${ }^{32}$ Una muestra que refrenda el riesgo de alabar a Lorca es la siguiente censura que hemos hallado sobre Pueblo en la "Hoja de inspección, año X; núm. 16" fechada el 19 de enero de 1948: “[...] En la página literaria, aparece la fotografía de García Lorca, entre otras" (documento consultado en el Archivo General de la Administración en el dossier titulado "Hoja de inspección. Año X"). Entretanto, Cántico asumió como propio este sintagma lorquiano que coronaba en letra mayúscula la contraportada de diecisiete de las diecinueve revistas publicadas: "Celeste Córdoba enjuta"; además Cántico dedicó a Lorca alguna columna laudatoria.
} 
que, naturalmente, no era concebido al margen de la realidad de las publicaciones españolas de entonces, igual que ocurre con la tópica.

Precisamente en lo tocante a los temas, es cierto que Cántico presenta muchos poemas de vates cristianos y católicos - como Paul Claudel—, aunque consideramos que es fundamentalmente por la propia predilección estética o religiosa ${ }^{33}$ de sus escritores y no simplemente por sortear la censura; es decir, no pensamos que la inclusión de asuntos religiosos fuera per se un subterfugio para burlar la censura. El mecanismo de autocensura se observa más bien en la elección de temas evocadores de la guerra y de sus consecuencias pero que no la abordan con explicitud. Se vislumbra así cierto compromiso social, aunque solapado, bajo un sentido ético de la existencia.

Las traducciones incluidas en Cántico invocan una ascendencia estética simbolista y de carácter modernista por lo que consideramos adecuado redefinir la poética del grupo que en muchas ocasiones ha sido considerada meramente como esteticista.

Con todo argüimos, como la conclusión general más destacada, el aperturismo y la heterogeneidad de la revista Cántico que fue capaz de aunar en las mismas páginas a una pléyade de poetas situados ideológicamente en las antípodas del franquismo con otro grupo de poetas bien relacionados con el régimen imperante en la postguerra. La revista Cántico, por tanto, aclimata a una saga de voces internacionales y acrisola un destacado ramillete de poemas en el panorama poético español. Por ello se colige que una característica sobresaliente de la revista cordobesa es su complejo eclecticismo junto a su altura de miras.

\section{REFERENCIAS BIBLIOGRÁFICAS}

ABELLÁN, M. (1980). Censura y creación poética en España (19391976). Barcelona: Península.

ALEIXANDRE, V.(2007). “Carta a los fundadores de Cántico”. En Cántico. Hojas de Poesía. Córdoba 1947-1957, VV.AA., 35-36. Córdoba:

\footnotetext{
${ }^{33}$ Sobre la religiosidad en Pablo García Baena, Manuel Vilas escribe que "los dioses de Baena guardan relación con los de Hölderlin y Jünger, viven ajenos a la corrupción del tiempo humano. El mismo catolicismo baeniano exilia, en su agudo sincretismo, el fantasma de la culpa, vencida siempre por el fluir sensual de las maravillas terrenales" (1995: 10).
} 
Consejería de Cultura de la Junta de Andalucía / Diputación de Córdoba. Delegación de Cultura / Fundación Cajasur.

ALEXANDER, M. (2007). A History of English Literature. New York: Palgrave.

ALTHUSSER, L. (1970). "Ideologie et appareils idéologiques d'État (Notes pour une recherche)". La Pensée 151, 67-125.

AMAT, J. (2003a). "Hilos de aproximación. El catalanismo dialogante y los Congresos de Poesía". Ínsula 684, 3-7.

(2003b). "'Las líneas divisorias nunca son del todo precisas'. Entrevista con Valentí Puig". Ínsula 684, 28.

(2007). Las voces del diálogo. Poesía y política en el medio siglo. Barcelona: Península.

ANAYA MARTÍNEZ, S. (1989). "Una lectura de Eugenio Montale". Estudios románicos 4, 75-84.

AUDEN, W. H. (1976). Collected Poems, Edward Mendelson, (ed.). London: Faber and Faber.

BARÓN, Emilio. (1994). "Gide y Cernuda: El moralista y su discípulo". Cauce: revista de filología y su didáctica 17, 121-134.

BENET, J. (1985). "Las libertades secuestradas". En La guerra civil española 50 años después. Una reflexión moral, AA.VV., 101-113. Barcelona: Labor.

BERNIER, J. (2011). Diario (1918-1947). Valencia: Pre-Textos.

BLANCO OUTÓN, C. (2000). "La España de posguerra y la poesía Anglófona: Traducción y recepción en las revistas Escorial, Espadaña y Cántico". Babel. Revue Internationale e Traduction 46.4, 332-356.

CARBÓ, F. (2006). “Quatre poemes amb gall en l'evolució de Joan Vinyoli”. Quaderns de Filologia. Estudis Literaris XI, 63-78.

CARNERO, G. (2009). El Grupo Cántico de Córdoba. Un episodio clave de la historia de la poesía española de posguerra. Madrid: Visor Libros.

DE BLAS, J. A. (2007). "La Delegación de Estado para Prensa y Propaganda y la censura de libros". Represura. Revista de Historia Contemporánea española en torno a la represión y la censura aplicadas al libro 3, s. p.

DESAINTGHISLAIN, C. et alii (1995). Français. Littérature \& Méthodes. Paris: Nathan. 
DIETZ, B. (1985). El impacto de la Guerra Civil española en la poesía inglesa (1936-1939). La Laguna: Secretariado de Publicaciones de la Universidad de La Laguna.

DOMBROSKI R. (2004). "The Rise and Fall of Fascism (1910-1945)". En The Cambidge History of Italian Literature, P. Brand \& L. Pertile (eds.), 491-530. Cambridge: Cambridge University Press.

ENTRAMBASAGUAS Y PEÑA, J. (1954). “Cántico reaparece”. Revista de literatura 6.10-12, 371.

FRANCO CARRILERO, M. F. (2015). "La censura y sus efectos en la poesía española del siglo XX". En De Re poetica: homenaje al profesor D. Manuel Martínez Arnaldos, José María Pozuelo Yvancos, Abraham Esteve Serrano, Francisco Vicente Gómez, Carmen Pujante Segura (coords.), 313-326. Murcia: Ediciones de la Universidad de Murcia.

GALLOFRÉ, M. J. (1989). "Entre la proscripció i la retallada: autors catalans en llengua castellana, 1942". Cuadernos Interdisciplinarios de Estudios Literarios 1, 165-175.

(1991). L'edició catalana i la censura franquista (1939-1962). Vol I. Barcelona: Publicaciones de L'Abadia de Montserrat.

GARBISU BUESA, M. (2002). Purismo español y hermetismo italiano: Coincidencias y divergencias en Jorge Guillén y Giuseppe Ungaretti. Madrid: Fundación Universitaria Española.

GARCÍA BAENA, P. (2007). "Nacimiento de Cántico". Cántico. Hojas de Poesía - Córdoba 1947-1957, VV.AA., xvii-xviii. Córdoba: Consejería de Cultura de la Junta de Andalucía / Diputación de Córdoba. Delegación de Cultura / Fundación Cajasur.

GARCÍA DE LA CONCHA, V. (1973). La poesía española de posguerra: teoría e historia de sus movimientos. Madrid: Editorial Prensa Española.

(1987). La poesía española de 1935 a 1975. II. De la poesía existencial a la poesía social 1944-1950. Madrid: Cátedra.

GONZÁLEZ SALVADOR, A. (1994). “La narración”. En Historia de la literatura francesa, J. del Prado (coord.), 1111-1168. Madrid: Cátedra.

GRACIA. J. (1993). "Los años cincuenta y la vía española de un catalanismo cultural". Sistema 112, 89-102.

GRACIA, J. y RÓDENAS MOYA, D. (2015). Pensar por ensayos en la 
España del siglo XX. Historia y repertorio. Barcelona: Servicio de Publicaciones de la Universidad Autónoma de Barcelona.

HURTLEY, J. A. (1989). "Translation in Postwar Spain: Twixt Survival and Interior Exile". Journal of Interdisciplinary Literary Studies $1.2,265-276$.

LOBEJÓN SANTOS, S. (2008). "La censura en la traducción de la poesía en inglés (1939-1978)", La traducción del futuro: mediación lingüística y cultural en el siglo XXI, L. Pegenaute, J. A. DeCesaris, M. Tricás Preckler y E. Bernal (coords.), vol. I, 241-250. Madrid: Promociones y Publicaciones Universitarias. (2009). "El catálogo TRACEpi (1939-1978). La traducción de poesía en inglés vista a través de la censura franquista". Interlingüistica $18,642-650$.

MANENT, A. (2003). “Monitor, revista literaria en catalán no autorizada por el franquismo". Ínsula 684, 7-11.

MEDINA, J. (2003). "La España de Riba y nuestra España”. Ínsula 684, $15-18$.

MOLINA, R. (1971). Función social de la poesía. Guadarrama: Fundación Juan March.

(1990). Diario (1937-1946), J. M. de la Torre (ed.). Córdoba: Fundación Cultura y Progreso.

MONTALE, E. (1981). Lettere a Salvatore Quasimodo, S. Grasso (ed.). Milano: Bompiani.

MONTEJO GURRUCHAGA, L. (2014). "La revista Fantasía. Semanario de la invención literaria (1945-1946). Narraciones olvidadas de autoría femenina". Lectura y Signo 9, 65-85.

MUÑOZCÁLIZ, B. (2005). El teatro crítico español durante el franquismo, visto por sus censores. Madrid: Fundación Universitaria Española. (2006). Expedientes de la censura teatral franquista. Vol I. Madrid: Fundación Universitaria Española.

NEUSCHÄFER, H. (1994). Adiós a la España eterna. La dialéctica de la censura. Novela, teatro y cine bajo el franquismo. Barcelona: Anthropos.

OSKAM, J. (1991). "Censura y prensa franquista como tema de investigación". Revista de estudios extremeños 47.1, 113-132.

PETRONIO, G. (1990). Historia de la literatura italiana, Manuel Carrera y M. ${ }^{a}$ de las Nieves Muñiz (trads.). Madrid: Cátedra. 
POPLAWSKI, P. (ed.) (2008). English Literature in Context. Cambridge: Cambridge University Press.

PUJOL, C. (1976). Abecé de la literatura francesa. Barcelona. Editorial Planeta.

RENDÓN, O. (2017). "Los años de Cántico". En Ricardo Molina. Dulce es vivir, O. Rendón (ed.), 61-82. Sevilla: Consejería de Cultura de la Junta de Andalucía / Centro Andaluz de las Letras.

REYES DE LA ROSA, J. (2008). "Ricardo Molina, traductor de poesía francesa en la revista Cántico". En Ricardo Molina, conciencia de "Cántico", A. Rodríguez Jiménez (ed.), 137-160. Sevilla: Renacimiento.

RIVERO MACHINA, A. (2016). Más allá de la posguerra: poesía y ámbito literario (1936-1950). Tesis doctoral dirigida por José Luis Bernal Salgado, Universidad de Extremadura.

(2017). Posguerra y poesía. Construcciones críticas y realidad histórica. Barcelona: Anthropos.

RODRÍGUEZ PUÉRTOLAS, J. (2008). Historia de la literatura fascista española. Tres Cantos: Akal.

ROMERO LÓPEZ, D. (1995). “Un tributo al análisis de las revistas españolas de posguerra españolas: Trabajos y dias (Salamanca, 1946-1951)". Salamanca. Revista de Estudios 35-36, 243-272.

RUBIO, F. (1976) (2003a). Las revistas poéticas españolas, 1939-1975. Alicante: Publicaciones de la Universidad de Alicante.

(2003b). "Las revistas contemporáneas (Homenaje a la revista Cántico)". En Cincuenta años de Cántico. Estudios críticos. C. Fernández Prieto y J. Roses Lozano (eds.), 55-64. Córdoba: Diputación Provincial de Córdoba.

SANTOS SÁNCHEZ, D. (2015). "Los aparatos teatrales de Estado. Una propuesta teórica para abordar las relaciones entre teatro y dictadura en la España de Franco". Ibero 82, 170-184.

TORRALBO CABALLERO. J. D. (2017a). "Un paso en la aclimatación de literatura extranjera en España: Internacionalización y apertura del Grupo Cántico". En: La tradición trascendida. Cántico y su época, Balbina Prior, (ed.), 46-58. Madrid: Ediciones de la Revista Áurea.

(2017b). “'Uriel': Ricardo Molina y la literatura foránea en las primeras hojas de Cántico", Ánfora Nova. Los dones de la dicha. 
Homenaje a Ricardo Molina, Antonio Moreno Ayora, (ed.), 111112, 91-106.

(2018a). 'La 'afín universalidad' de la revista Cántico: Presentación y estudio de los transvases internacionales". Impossibilia 16, 136171.

(2018b). "Literatura inglesa en las hojas de Cántico". Monteagudo 23, 169-186.

(2019). La traducción de literatura italiana en la revista Cántico. Sevilla: Arcibel.

VELÁZQUEZ EZQUERRA, J. I. (1994). "La poesía”. En Historia de la literatura francesa, J. del Prado (coord.), 1169-1257. Madrid: Cátedra.

VILAS, M. (1995). "Pablo García Baena, et in arcadia ego". Revista de poesía. Poesía en el campus. Pablo García Baena 32, 4-11.

VV.AA. (2007). Cántico. Hojas de Poesía. Córdoba 1947-1957. Córdoba: Consejería de Cultura de la Junta de Andalucía / Diputación de Córdoba. Delegación de Cultura / Fundación Cajasur.

WRIGHT, E. (1986). The Poetry of Protest under Franco. London: Tamesis Books Limited.

Recibido el 28 de marzo de 2019.

Aceptado el 12 de junio de 2019. 